Ann. Anim. Sci., Vol. 12, No. 4 (2012) 621-631, DOI: 10.2478/v10220-012-0052-0

\title{
EFFECT OF SLAUGHTER AGE ON PERFORMANCE AND MEAT QUALITY OF SLOW-GROWING BROILER CHICKENS*
}

\author{
Katarzyna Połtowicz, Joanna Doktor \\ Department of Animal Genetics and Breeding, National Research Institute of Animal Production, \\ 32-083 Balice n. Kraków, Poland
}

\begin{abstract}
The aim of the study was to determine the effect of age of slow-growing broiler chickens on growth performance and meat quality. Subjects were hybrids between Hubbard meat-type cockerels and Yellowleg Partridge Polish native hens. Chickens were raised indoors to 56, 70 or 84 days of age on deep litter under the same environmental conditions and fed ad litibum complete starter, grower and finisher diets containing 20, 18, $15 \mathrm{CP}$ and 2825,2825 and $2740 \mathrm{ME} / \mathrm{kg}$ feed, respectively. At the end of the experiment, 5 cockerels and 5 pullets were selected for slaughter from each age group and subjected to a simplified carcass analysis. Breast muscles and leg muscles were evaluated for technological properties such as $\mathrm{pH}$, colour, water holding capacity, drip loss, cooking loss and shear force. The results were analysed statistically using analysis of variance and Duncan's multiple range test. The duration of rearing had an effect on carcass and meat quality. The highest, statistically significant differences in the analysed traits were found between chickens slaughtered at 56 and 84 days of age. The highest dressing percentage was obtained in birds raised until 84 days of age. Youngest birds were characterized by the poorest muscle content of the carcass and the least favourable technological properties of meat. The highest growth efficiency was obtained when the hybrids were raised to 70 days of age.
\end{abstract}

Key words: broiler chickens, slow growing, hybrid, age, meat quality

Some of the most important factors affecting the quality of poultry meat are origin and slaughter age. They mainly determine the organoleptic attributes of meat, but also have an effect on its technological properties. In the modern intensive poultry production, age at slaughter depends on whether birds attain the desired body weight, and for many years the duration of rearing has tended to decrease. This course of action is dictated by the desire to improve the economic results of rearing meat chickens, which should be slaughtered immediately after the birds reach the maximum rate of weight gain. On the other hand, the increasingly popular organic production

*This study was financed from funds for NRIAP statutory activity, project no. 1230.1 . 
system has forced poultry producers to slow the rate of growth and to extend the housing period. In this case, choosing the appropriate genetic type of the birds becomes a major problem. Many studies have shown that it is very expensive to slow the growth rate of high-producing genetic lines of chickens through the environment (Cahaner et al., 2008). Moreover, conventional Cornish $\times$ White Plymouth Rock crosses were developed for production in indoor, climate-controlled conditions, and they may not be appropriate for alternative systems where conditions are not well controlled (Fanatico et al., 2007). It is also thought that animals genetically selected due to high production efficiency are more at risk for behavioural, physio-biological and immunological problems (Rauw et al., 1998). Therefore, in this type of production it seems most appropriate to use slow-growing lines of broiler chickens developed using local populations. Use of slow-growing strains has also positive repercussions on both animal welfare and product qualitative characteristics perceived by consumers (Castellini et al., 2008) and may be more suitable for niche markets. However, slower growing birds are rarely used in Poland. The slow-growing lines of chickens from foreign producers are sometimes used in alternative poultry meat production systems. Our studies show that native breeds of chickens can be used for this purpose (Połtowicz et al., 2004, 2005), but the amount of meat obtained from them is small due to their low body weight and considerably lower breast meat yield compared to broilers. At the same time, this meat is characterized by valuable culinary and dietetic qualities, including the high protein content and the low fat content.

There is some debate among breeders about whether to base production of "village" chickens on fast-growing lines adapted for this purpose or to begin breeding work to improve the productivity of local populations. Most often, however, local populations are improved using high-producing lines (Besbes, 2009). In this case, determination of the optimum duration of rearing hybrids requires thorough analysis that includes avian productivity but also the quality of the material obtained. Therefore, all such aspects must be considered to decide which is the ideal slaughter age according to the final product to be commercialized.

The aim of the study was to evaluate production results, dressing percentage, and carcass and meat quality in slow-growing broiler chickens obtained by commercial crossbreeding of meat-type cockerels and Yellowleg Partridge Polish hens according to the duration of rearing.

\section{Material and methods}

Subjects were slow-growing Hubbard $\times$ Yellowleg Partridge hybrids. Day-old chicks $(n=180)$ were placed in a deep-litter facility in three compartments, each containing 60 birds, with a stocking density of $12 \mathrm{birds} / \mathrm{m}^{2}$. All birds were fed ad libitum complete starter, grower and finisher diets containing 20, 18, $15 \mathrm{CP}$ and 2825, 2825 and $2740 \mathrm{ME} / \mathrm{kg}$ feed, respectively. During rearing, individual body weight of the chickens and their feed intake was recorded every two weeks and the number 
of dead birds every day. Chickens were reared to 56 (group I), 70 (group II) and 84 (group III) days of age. At the end of the experiment, 10 chickens ( 5 cockerels and 5 pullets) with average body weight were selected. Birds were slaughtered to determine dressing percentage, carcass quality and physico-chemical properties of meat. All carcasses were chilled by air, under the same conditions, by placing them in a cold store at $4^{\circ} \mathrm{C}$ immediately after evisceration and weighing. After 24 hours of chilling carcasses were reweighed and dressing percentage with and without giblets was determined as the proportion of the weight of chilled eviscerated carcass (with and without giblets, respectively) to the preslaughter body weight of the chickens.

Chilled carcasses were subjected to a simplified carcass analysis, the results of which were used to calculate the proportion of breast muscles, leg muscles, leg bones, giblets and abdominal fat in the carcass with giblets. Carcass colour was determined using the CIE L*a*b* system (Minolta CR310, Japan). To this end, each carcass was subjected to 6 measurements on undamaged, blood spot-free surface of the skin of breast, thigh and back, and means were calculated for L* (lightness), $a^{*}$ (redness) and $b^{*}$ (yellowness) coordinates. The difference between the weight of hot and cold carcass was used to calculate the loss due to 24-hour cold storage of the carcasses at $4^{\circ} \mathrm{C}$. The analysis of physico-chemical properties of meat included initial $\left(\mathrm{pH}_{15 \mathrm{~min}}\right)$ and final $\mathrm{pH}\left(\mathrm{pH}_{24 \mathrm{~h}}\right)$ of breast muscles and leg muscles, their colour, expressible juice, drip loss, cooking loss, and shear force of cooked breast muscles. The initial and final $\mathrm{pH}$ of the muscles was determined based on direct measurement of $\mathrm{pH} 15$ min and $24 \mathrm{~h}$ postmortem by placing an ion-selective glass electrode halfway through the thickness of pectoralis superficialis muscle and thigh muscles. Measurements were made with a CyberScan $10 \mathrm{pH}$ meter. Prior to the tests, the electrode was subjected to a two-point calibration in calibration buffers $\mathrm{pH} 4.01$ and 7.00 whose temperature was close to measurement temperature. Muscle colour (CIE $\mathrm{L} * \mathrm{a} * \mathrm{~b}$ ) was determined $24 \mathrm{~h}$ postmortem using a Minolta CR310 chroma meter. Inner surface of the pectoralis superficialis muscle and thigh muscles was analysed immediately after deboning. Samples were collected from the prepared muscles for determination of expressible juice using the method described by Grau and Hamm (1953). Drip loss was determined $48 \mathrm{~h}$ postmortem based on percentage loss of muscle weight during 24 -hour cold storage at $4^{\circ} \mathrm{C}$. The cooking loss was measured on samples of about $80 \mathrm{~g}(\mathrm{e}=0.001 \mathrm{~g})$ placed individually in the plastic bags and cooked in water bath at $100^{\circ} \mathrm{C}$ for about $15 \mathrm{~min}$ to an internal temperature of $78^{\circ} \mathrm{C}$. The cooking loss was estimated as the percentage of the weight of the cooked samples (cooled and dried on the surface with a paper towel) with respect to the weight of the raw samples. Shear force was evaluated on cores $(1.27 \mathrm{~cm}$ diameter and $3 \mathrm{~cm}$ length) obtained from the thickest part of the cooked samples by cutting them perpendicularly to the direction of the fibre, using an Instron model 5542 equipped with a Warner-Bratzler meat shear apparatus. The results were analysed statistically using analysis of variance and significant differences between groups were determined by Duncan's multiple range test (Statgraphic Plus 6.0). 


\section{Results}

The chickens raised to 56, 70 and 84 days of age reached a body weight of 1.22 , 1.70 and $2.17 \mathrm{~kg}$ and used $1.90,2.00$ and $2.18 \mathrm{~kg}$ of the diet per $\mathrm{kg}$ weight gain (Table 1). The best growth performance was achieved by chickens raised to 70 days of age, for which the European Efficiency Index (EEI) was 117.9 pts, but their advantage in EEI over chickens from groups I and III was small (6 and 5 pts, respectively). The study showed a significant effect of chickens' age on their dressing percentage and carcass quality (Table 2). The highest dressing percentage (almost 74\% with giblets) was found in birds slaughtered at 84 days of age. Compared to these birds, the dressing percentage of chickens from groups I and II was lower by $3.41 \%$ $(\mathrm{P} \leq 0.001)$ and $1.05 \%(\mathrm{P}>0.05)$, respectively. Also carcass muscle content increased as chickens became older. The total proportion of breast muscles and leg muscles in 56-, 70- and 84-day-old broilers was 38.72, 41.50 and $41.53 \%$, respectively. A more pronounced, statistically significant tendency towards a consistent improvement in muscle content was found in older chickens for legs. A significant increase in the proportion of breast muscles in the carcass was only noted between 56 and 70 days of age, with further extension of rearing having no significant effect on this parameter. The study showed a marked tendency towards a decrease in the proportion of bones and giblets in the carcasses of older chickens. The age of birds significantly reduced the proportions of liver and gizzard, but had no significant effect on heart percentage. There was no consistent tendency in carcass fatness from differently aged slow-growing broilers in which the proportion of abdominal fat ranged from $1.22 \%$ (group II) to $1.73 \%$ (group III). The age of chickens had no effect on carcass colour. In all the groups, colour parameters were similar and their values averaged $69.09\left(\mathrm{~L}^{*}\right), 4.82\left(\mathrm{a}^{*}\right)$ and $8.56\left(\mathrm{~b}^{*}\right)$.

Table 1. Production results of slow-growing chickens

\begin{tabular}{l|c|c|c}
\hline & \multicolumn{3}{|c}{ Age at slaughter } \\
\cline { 2 - 4 } & 56 days & 70 days & 84 days \\
\hline Body weight (g) & 1217 & 1705 & 2126 \\
Feed conversion (g/kg gain) & 1896 & 2000 & 2181 \\
Mortality (\%) & 2.92 & 2.92 & 2.92 \\
EEI (pts) & 111.9 & 117.9 & 112.9 \\
\hline
\end{tabular}

The results showed that the duration of rearing slow-growing chickens had a significant effect on most physico-chemical properties of their meat. In both breast and leg muscles, $\mathrm{pH}_{24 \mathrm{~h}}$ tended to be significantly higher in older chickens, although a reverse tendency was found for $\mathrm{pH}_{15 \mathrm{~min}}$. The lightest breast muscles were obtained from the youngest chickens aged 56 days $\left(\mathrm{L}^{*}=59.37\right)$. At the same time, the muscles of these birds were characterized by greater yellowness $\left(b^{*}=8.07 ; \mathrm{P}>0.05\right)$ compared to other groups. The muscles of different aged chickens exhibited differences in water holding capacity. The highest drip loss and expressible juice were characteristic of the breast muscles from group I chickens. Drip loss tended to decrease significant- 
ly as rearing lengthened. Drip loss from the breast muscles of chickens slaughtered at 84 days of age $(0.68 \%)$ was almost half that of 56-day-old birds. The cooking loss from breast muscles ranged from $19.30 \%$ in group II to $20.06 \%$ in group III, with non-significant differences between the groups. Analysis of the water holding capacity of leg muscles showed that it tended to improve with chickens' age. In the case of these muscles, a significant decrease was also found for cooking loss $(\mathrm{P} \leq 0.05)$. The highest shear force $(22.84 \mathrm{~N})$ was characteristic of the breast muscles of chickens reared the longest. Compared to the breast muscles of 70- and 56-day-old chickens, the muscles of the oldest chickens were tougher, as evidenced by significant shear force differences of $4.09 \mathrm{~N}(\mathrm{P} \leq 0.05)$ and $6.11 \mathrm{~N}(\mathrm{P} \leq 0.001)$, respectively.

Table 2. Results of carcass quality of slow-growing chickens $(x \pm \mathrm{SD})$

\begin{tabular}{l|c|c|c}
\hline & \multicolumn{3}{|c}{ Age at slaughter } \\
\cline { 2 - 4 } & 56 days & 70 days & 84 days \\
\hline Carcass weight loss during chilling (\%) & $2.75 \pm 0.28 \mathrm{AA}$ & $2.24 \pm 0.55 \mathrm{~B}$ & $1.71 \pm 0.29 \mathrm{BA}$ \\
Dressing percentage with giblets & $70.55 \pm 1.40 \mathrm{Aa}$ & $72.91 \pm 1.47 \mathrm{~b}$ & $73.96 \pm 2.75 \mathrm{~B}$ \\
Dressing percentage without giblets & $66.29 \pm 1.46 \mathrm{AA}$ & $69.07 \pm 1.65 \mathrm{~B}$ & $70.66 \pm 2.72 \mathrm{~B}$ \\
Breast muscles (\%) & $19.16 \pm 1.17 \mathrm{a}$ & $20.86 \pm 1.27 \mathrm{~b}$ & $20.29 \pm 1.91$ \\
Leg muscles (\%) & $19.56 \pm 0.92 \mathrm{Aa}$ & $20.64 \pm 1.08 \mathrm{~b}$ & $21.24 \pm 1.02 \mathrm{~B}$ \\
Leg bones (\%) & $6.13 \pm 0.70 \mathrm{a}$ & $5.82 \pm 0.61$ & $5.44 \pm 0.75 \mathrm{~b}$ \\
Giblets (\%) & $6.06 \pm 0.56 \mathrm{a}$ & $5.27 \pm 0.66$ & $4.46 \pm 0.28 \mathrm{~b}$ \\
Liver (\%) & $3.25 \pm 0.40 \mathrm{~A}$ & $2.55 \pm 0.35 \mathrm{Ba}$ & $2.25 \pm 0.17 \mathrm{Bb}$ \\
Gizzard (\%) & $2.08 \pm 0.33 \mathrm{~A}$ & $2.01 \pm 0.41 \mathrm{~A}$ & $1.60 \pm 0.15 \mathrm{~B}$ \\
Heart (\%) & $0.73 \pm 0.10$ & $0.71 \pm 0.22$ & $0.62 \pm 0.11$ \\
Abdominal fat (\%) & $1.53 \pm 0.49$ & $1.22 \pm 0.62$ & $1.73 \pm 0.94$ \\
L* & $70.03 \pm 1.22$ & $68.15 \pm 6.23$ & $69.08 \pm 1.55$ \\
a* & $4.66 \pm 0.72$ & $4.94 \pm 0.56$ & $4.85 \pm 0.64$ \\
b* & $8.31 \pm 1.46$ & $8.53 \pm 1.63$ & $8.84 \pm 1.52$ \\
\hline
\end{tabular}

Means in rows with different letters ab differ at $\mathrm{P} \leq 0.05 ; \mathrm{AB}$ at $\mathrm{P} \leq 0.01 ; \mathbf{A B}$ at $\mathrm{P} \leq 0.001$.

Table 3. Results of breast muscle quality of slow-growing chickens $(x \pm S D)$

\begin{tabular}{|c|c|c|c|}
\hline & \multicolumn{3}{|c|}{ Age at slaughter } \\
\hline & 56 days & 70 days & 84 days \\
\hline$\overline{\mathrm{pH}_{15 \min }}$ & $6.28 \pm 0.22$ & $6.17 \pm 0.14$ & $6.17 \pm 0.09$ \\
\hline $\mathrm{pH}_{24 \mathrm{~h}}$ & $5.83 \pm 0.04 \mathbf{A}$ & $6.10 \pm 0.12$ B & $6.03 \pm 0.11 \mathbf{B}$ \\
\hline $\mathrm{L}^{*}$ & $59.37 \pm 1.33 \mathrm{a}$ & $57.34 \pm 1.36 \mathrm{~b}$ & $58.08 \pm 2.45$ \\
\hline$a^{*}$ & $10.56 \pm 0.58$ & $11.16 \pm 1.13 \mathrm{~A}$ & $9.91 \pm 0.90 \mathrm{~B}$ \\
\hline$b^{*}$ & $8.07 \pm 0.69$ & $7.34 \pm 1.05$ & $7.25 \pm 0.96$ \\
\hline Expressible juice (\%) & $19.90 \pm 1.73$ & $17.94 \pm 1.52$ & $18.14 \pm 3.43$ \\
\hline 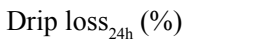 & $1.20 \pm 0.41 \mathrm{Aa}$ & $0.80 \pm 0.42 \mathrm{~b}$ & $0.68 \pm 0.20 \mathrm{~B}$ \\
\hline Cooking loss $(\%)$ & $19.38 \pm 1.87$ & $19.30 \pm 2.10$ & $20.06 \pm 1.82$ \\
\hline Shear force $(N)$ & $16.73 \pm 2.61 \mathbf{A}$ & $18.75 \pm 3.11 \mathrm{a}$ & $22.84 \pm 4.02 \mathrm{Bb}$ \\
\hline
\end{tabular}

For explanations, see Table 2. 
Table 4. Results of leg muscle quality of slow-growing chickens $(x \pm \mathrm{SD})$

\begin{tabular}{l|c|c|c}
\hline \multirow{2}{*}{} & \multicolumn{3}{|c}{ Age at slaughter } \\
\cline { 2 - 4 } & 56 days & 70 days & 84 days \\
\hline $\mathrm{pH}_{15 \min }$ & $6.49 \pm 0.15$ & $6.40 \pm 0.16$ & $6.38 \pm 0.13$ \\
$\mathrm{pH}_{24 \mathrm{~h}}$ & $5.97 \pm 0.08 \mathrm{~A}$ & $6.27 \pm 0.15 \mathbf{~ B}$ & $6.30 \pm 0.18$ B \\
$\mathrm{L}^{*}$ & $48.08 \pm 1.81 \mathrm{~A}$ & $44.36 \pm 1.84 \mathbf{~ B}$ & $43.99 \pm 2.08 \mathbf{B}$ \\
$\mathrm{a}^{*}$ & $16.86 \pm 0.86 \mathrm{~A}$ & $18.00 \pm 0.95 \mathrm{~B}$ & $16.89 \pm 0.85 \mathrm{~A}$ \\
$\mathrm{~b}^{*}$ & $6.15 \pm 0.86$ & $5.81 \pm 0.87$ & $5.68 \pm 0.87$ \\
Expressible juice (\%) & $18.05 \pm 3.63$ & $15.86 \pm 2.60$ & $15.11 \pm 3.39$ \\
Drip loss $_{24 \mathrm{~h}}(\%)$ & $0.70 \pm 0.29 \mathrm{~A}$ & $0.41 \pm 0.17 \mathrm{~B}$ & $0.40 \pm 0.19 \mathrm{~B}$ \\
Cooking loss (\%) & $30.41 \pm 4.64 \mathrm{a}$ & $28.41 \pm 2.66$ & $26.11 \pm 4.63 \mathrm{~b}$ \\
\hline
\end{tabular}

For explanations, see Table 2.

\section{Discussion}

Practical experience in poultry farming has indicated a close relationship between the duration of rearing and the ultimate economic effect of broiler chicken production. Feed costs form the greatest proportion of all costs of producing $1 \mathrm{~kg}$ live birds. Therefore, the attainment of good production results is conditional on the efficient use of feeds. Our results indicate that Hubbard $\times$ Yellowleg Partridge chickens needed 84 days and used almost $2.2 \mathrm{~kg}$ feed per $\mathrm{kg}$ gain to obtain a slaughter weight of about $2.1 \mathrm{~kg}$, whereas fast-growing commercial broilers can already reach the same body weight at 37 days of rearing with the use of $1.62 \mathrm{~kg}$ feed per $\mathrm{kg}$ gain (www.hubbardbreeders.com). Meanwhile, during a 98-day growth period, purebred Yellowleg Partridge chickens achieve much lower body weights (1420 g) and use over $4.2 \mathrm{~kg}$ feed per kg gain (Połtowicz, unpublished data). Compared to the slowgrowing commercial hybrids Hubbard JA-757 and JA-957, available on the Polish market, the chickens studied by us (Hubbard $\times$ Yellowleg Partridge) had poorer production results. According to the data made available by the owner of the breeding stock, during 56 days of rearing the commercial hybrids achieve a body weight of about $2.3 \mathrm{~kg}$ and use an average of $2.15 \mathrm{~kg}$ feed per $\mathrm{kg}$ gain. Compared to these birds, feed conversion by our hybrids remained at similar levels but they needed much more time to obtain similar body weights. This caused the growth efficiency of the chickens analysed in our study, expressed in terms of EEI, to be as low as 113 pts. By way of comparison, the EEI index of JA-957 chickens, performance tested in 2009, averaged 171.2 pts. Compared to the growth performance of Barred Rock cockerels $\times$ New Hampshire hens reported by Koreleski et al. (2008), the Hubbard $\times$ Yellowleg Partridge chickens achieved 88 and 187 g lower body weight at 70 and 84 days of age, respectively, but at the same time used less feed per $\mathrm{kg}$ gain. Our hybrids were characterized by lower feed conversion ratio (by $0.6 \mathrm{~kg}$ on average) also compared to their slow-growing contemporaries I 657, S 757 and S 666 (www.hubbardbreeders.com), but at the same time achieved lower body weights (by 153, 85 and $74 \mathrm{~g}$ at 
56, 70 and 84 days of age, respectively). Our research has confirmed the well-known fact that feed intake per kg gain increases as chickens grow older, but age at slaughter had no effect on the economic outcome of rearing these birds.

In commercial chickens the yield of most carcass parts depends on the slaughter age. Brake et al. (1993) and Young et al. (2001) noticed larger parts of breasts in older chickens. Albuquerque et al. (2003) showed that 56- and 49-day-old chickens had a greater breast portion of the carcass and higher yield of breast muscles compared to younger broilers aged 42 days. Likewise, Young et al. (2001), who studied Ross $\times$ Ross chickens at 37, 39, 42, 44, 46, 49 and 51 days of age, found that the yields of thighs, forequarters, breasts, and fillets increased as slaughter age increased, especially after 42 days. Meanwhile, Szkucik et al. (2007) demonstrated that Cobb broilers slaughtered at the age of 32, 38 or 44 days differed significantly only in body weight, while their dressing percentage, proportion of muscles and proportion of abdominal fat in cold carcass showed small differences with advancing rearing period. A study by Horsted et al. (2005) with slow-growing New Hampshire, I 657 and Light Sussex chickens shows that the yield of eviscerated carcass in these birds changed with age. Dressing percentage in 91-day-old chickens ranged from 65.42 to $71.78 \%$, with an average increase of 2.45 percentage points between 91 and 120 days of rearing. Compared to these values, dressing percentage without giblets in the 84-day-old hybrids analysed in our study was mostly higher. Only the I 657 commercial chickens achieved better results than the hybrids investigated in our study. In keeping with most research results available, dressing percentage in the hybrids analysed in our study increased with age. As the rearing period progressed, improvements were also seen in body muscling and the meat to bone ratio, and our findings support the earlier observations of Albuquerque et al. (2003) and Nikolova and Pavlovski (2009). Unlike many other authors, we failed to confirm the effect of chickens' age on body fatness in our study. Jiang and Huanlu (2004) reported that the ability to use energy to synthesize fats increased with weeks of age. However, Chang et al. (2010) demonstrated that breed is a key determinant of the level of body fatness in chickens. The same authors showed that the proportion of fat, which increased with age in the breast muscles of slow-growing chickens was significantly lower than in fast-growing chickens. Also in our study, the long, 84-day period of growth did not increase the hybrids' body fatness, which was probably due to the slow rate of growth of these birds. Similar to Brake et al. (1993), in our study the proportion of giblets in the carcass decreased in older birds.

Many studies indicate that the slaughter age of farm animals determines the physico-chemical characteristics of their meat. Regarding poultry, some findings going back more than 40 years assessed that age of birds mainly affects the tenderness and juiciness of the meat, which generally decreases as chickens become older (Castellini et al., 2008). On the other hand, Horsted et al. (2005) reported that age-related changes in tenderness and toughness differed significantly between strains, and commercial line (I 675) tends towards a tougher and less tender consistency of the breast meat, whereas the opposite was the case for the slower growing pure breeds (New Hampshire and Light Sussex). In our study, the meat from older chickens was less tender, which agrees with the observations of Horsted et al. (2005) concern- 
ing the I 675 commercial hybrids. Likewise, Northcutt et al. (2001) reported that age at slaughter had a significant effect on Warner-Bratzler shear values of broiler breast fillets, and their results indicate that the texture of the younger birds' meat is more desirable. Similarly, Poole et al. (1999) showed that breast fillets from broilers processed at 5 weeks of age had significantly lower Warner-Bratzler shear values compared to any of the other sampling ages $(6,7$ and 8 weeks). At the same time, Warner-Bratzler shear values for meat samples from 6- to 8-week-old birds did not vary significantly from one another. The same authors also reported that slaughter age had no effect on the cooking loss of meat. According to Northcutt et al. (2001), the age of chickens determined the cook yield of the meat with the lower yield values originating from 37-day-old broilers $(76 \%)$, and the higher yield values originating from 39- and 51-day-old birds (81\%). In our study, the cook yield of breast muscles averaged $80.42 \%$ with no significant differences between the age groups of the birds. In the case of leg muscles, the cook yield depended on chickens' age and ranged from $69.59 \%$ (56 days of age) to $73.89 \%$ ( 84 days of age).

It is well known that the rate and the amplitude of acidification have a strong effect on both organoleptic and technological parameters of meat quality (Duclos et al., 2007). Szałkowska and Meller (1998) and Pudyszak et al. (2005), when investigating the effect of the duration of rearing on meat quality, observed a tendency towards a decrease in muscle $\mathrm{pH}$ with the age of chickens and guinea fowl, respectively. As reported by Northcutt et al. (1998), the age of turkeys (5, 9, 13 or 17 weeks) affects the activity of proteolytic enzymes that play a key role in shaping the physico-chemical properties of meat. According to Moran (1999), muscle composition changes with chickens' age, with the greatest changes taking place at the inflection point in growth. Differences in the composition of meat concern, among others, the content of fat, collagen and myoglobin. As a general rule, myoglobin increases with age, shifting the meat colour towards darker and redder tonalities (Fletcher, 2002). Similarly, Bianchi et al. (2006) showed that the age of chickens influences the colour of meat. Boni et al. (2010) found that the meat from quail of different age (8 weeks vs. 8 months old) differed significantly in colour and acidity. The meat from young quail had significantly higher lightness $\left(\mathrm{L}^{*}\right)$ values and lower $\mathrm{a}^{*}$ and $\mathrm{b}^{*}$ values compared with the meat from spent quail. Also in our study, despite the much smaller age difference between the analysed groups of birds, the highest $L^{*}$ values were obtained for the muscles of the youngest chickens. Similar observations were made by Delpech et al. (1983), according to whom the increasing age was associated with darker breast meat colour in broilers. In contrast, Smith et al. (2002) who compared breast fillets from birds processed at different ages (from 42 to 52 days) reported that breast meat colour was not affected by the age. According to Bianchi et al. (2006), the colour of breast muscles depends on chickens' body weight and is darker in heavier birds. Berri et al. (2007) demonstrated that breast weight and yield were negatively correlated with glycogen levels, and these changes resulted in breast meat with greater $\mathrm{pH}$ and consequently darker colour and greater water holding capacity. Similar tendencies occurred in our study, in which larger breast muscles and leg muscles from older and at the same time heavier birds were characterized by higher $\mathrm{pH}_{24 \mathrm{~h}}$, lower drip loss and darker colour. The greatest differences in the physico-chemical properties of 
meat were found between the youngest (56-day-old) birds and those representing the other age groups (70 and 84 days old), with the concurrent lack of significant differences between 70- and 84-day-old chickens. It is also worth noting that immediately after slaughter, both types of muscles from the youngest birds showed a tendency towards higher $\mathrm{pH}_{15 \min }$ compared to the other age groups. However, after 24-hour cold storage of the carcasses, the $\mathrm{pH}$ of meat in the younger birds decreased to reach significantly lower values than in the older chickens. Such a marked decrease in the $\mathrm{pH}$ of muscles from the youngest chickens could thus negatively affect the quality of their meat (e.g. the drip loss or the lightness). These relationships were often reported for chickens and turkeys (Owens and Sams, 2000; Van Laack et al., 2000; Le BihanDuval et al., 2001; Fraqueza et al., 2006).

The results indicated that local populations improved with high-producing lines can be a source of slow-growing hybrids which can be used for poultry meat production. However, the amount and the quality of the meat obtained from them depends on the slaughter age.

\section{References}

Albuquerque R., Farida D.E., Junqueira O.M., Salvador D., Faira Filho D.E., R i z z o M.F. (2003). Effect of energy level in finisher diets and slaughter age on the performance and carcass yield in broiler chickens. Rev. Bras. Cienc. Avic., 5: 2.

Berri C., Le Bihan-Duval E., Debut M., Sante-Lhoutellier V., Baeza E., G i g a u d V., J e g o Y., D u c l o s M.J. (2007). Consequence of muscle hypertrophy on characteristics of Pectoralis major muscle and breast meat quality of broiler chickens. J. Anim. Sci., 85: 2005-2011.

B e s b e s B. (2009). Genotype evaluation and breeding of poultry for performance under suboptimal village conditions. World Poultry Sci. J., 65: 260-271.

Bianchi M., Petracci M., Cavani C. (2006). The influence of genotype, market live weight, transportation, and holding conditions prior to slaughter on broiler breast meat color. Poultry Sci., 85: $123-128$.

B on i I., N u rul H., N ory a ti I. (2010). Comparison of meat quality characteristic between young and spent quails. Int. Food Res. J., 17: 661-666.

B rake J., Haven s te in G.B., S c h e i d e le r S.E., F e r k e t P.R., Rive s D.V. (1993). Relationship of sex, age, and body weight to broiler chicken carcass yield and offal production. Poultry Sci., 74: $1137-1145$.

Cahaner A., Druyan S., Hadad Y., Yadgari L., Astrachan N., Kalinowski A., R o m o G. (2008). Breeding broilers for tolerance to stress. Proc. XXIII World's Poultry Congress, Australia, p. 253.

Castellini C., Berri C., Le Bihan-Duval E., Martino G. (2008). Qualitative attributes and consumer perception of organic and free-range poultry meat. World Poultry Sci. J., 64: $500-512$.

Chang G.B., Le i L.L., Zha ng X.Y., W ang K.H., Chen R., Lu a n D.Q., Chen G.H. (2010). Development rule of intramuscular fat content in chicken. J. Anim. Vet. Adv., 9 (2): 297-298.

Delpech P., D u m on t B.L., N e f z a ou i A. (1983). Influence du rationnement et du patrimoine génétique ds poluets sur les caractéristiques physic-chimiques et sensorilles de la viande à differents ages. Proc. 6th European Symposium on the Quality of Poultry Meat, France, pp. 21-27.

Duclos M.J., B erri C., Le B ihan-Duval E. (2007). Muscle growth and meat quality. J. Appl. Poultry Res., 16: 107-112.

F a n a t i c o A.C., P i 11 a i P.B., E m m e r t J.L., O w e n s C.M. (2007). Meat quality of slow- and fastgrowing chicken genotypes fed low-nutrient or standard diets and raised indoors or with outdoor access. Poultry Sci., 86: 2245-2255.

F le t c h e r D.L. (2002). Poultry meat quality. World Poultry Sci. J., 58: 131-145. 
Fraqueza M.J., Cardos o A.S., Ferreira M.C., B arreto A.S. (2006). Incidence of pectoralis major turkey muscles with light and dark color in Portuguese slaughterhouse. Poultry Sci., 85: 1992-2000.

Gr a u R., H a m m R. (1953). Eine einfache Methode zur Bestimmung der Wasserbindung im Muskel. Naturwiss, 40 (1): 29-30.

Horsted K., Henning J., Hermans en J.E. (2005). Growth and sensory characteristics of organically reared broilers differing in strain, sex and age at slaughter. Acta Agr. Scand. A - An., 55: $149-157$.

Jiang X., Huanlu S. (2004). Measurements and analysis of intra-muscular fat and fatty acid in poultry meat. J. Food Sci. Biotechnol., 23 (5): 26-28.

Koreleski J., Św i ą tki e wi c z S., A r c zews k a A. (2008). Dual-purpose slow-growing chickens for meat production. Ann. Anim. Sci., 8: 281-287.

Le Bihan-Duval E., Millet N., Remignon H. (2001). Estimation of genetic parameters of meat characteristics and of their correlations with growth and body composition in an experimental broiler line. Poultry Sci., 80: 839-843.

Moran E.T. (1999). Live production factors influencing yield and quality of poultry meat. Poultry meat science. Richardson and Mead. CABI Publishing, pp. 179-195.

Nikolova N., Pavlovski Z. (2009). Major carcass parts of broiler chickens from different genotype, sex, age and nutrition system. Biotechnol. Anim. Husb., 25 (5-6): 1045-1054.

Northcutt J.K., Pringle T.D., Dickens J.A., Buhr R.J., Young L.L. (1998). Effect of age and tissue type on the calpain proteolytic system in turkey skeletal muscle. Poultry Sci., 77: 367-372.

N o r th cut t J.K., B u h r R.J., Y o ung L.L., L y o n C.E., W a r e G.O. (2001). Influence of age and postchill carcass aging duration on chicken breast fillet quality. Poultry Sci., 80: 808-812.

O w e n s C.M., S a m s A.R. (2000). The influence of transportation on turkey meat quality. Poultry Sci., 79: 1204-1207.

P ołtow ic z K., W ężyk S., Ca lik J., Paściak P. (2004). The use of native chicken breed in poultry meat production. Proc. British Society of Animal Science, Krakow, p. 30.

P ołt ow i c z K., W ęży k S., Ca lik J., C y wa - B en k o K., K r a w c zy k J. (2005). Effect of free range management on carcass muscling and meat quality in Sussex and Rhode Island Red cockerels. Ann. Anim. Sci., Supl. 2: 149-151.

P o o l e G.H., L y o n C.E, B u h r R.J., Y o ung L.L. (1999). Evaluation of age, gender, strain, and diet on the cooked yield and shear values of broiler breast fillets. J. Appl. Poultry Res., 8: 170-176.

Pudyszak K., Pomiankowski J., Majewska T. (2005). Slaughter value and meat quality of guinea fowls slaughtered at a different age (in Polish). Żywność. Nauka. Technologia. Jakość, 1 (42): 27-34.

Rauw W.M., Kan is E., Noordhuizen-Stas sen E.N., Grommers F.J. (1998). Undesirable side effect of selection for high production efficiency in farm animals: a review. Liv. Prod. Sci., 56: 15-33.

S $\mathrm{m}$ i th D.P., L y o n C.E., L y o n B.G. (2002). The effect of age, dietary carbohydrate source, and feed withdrawal on broiler breast fillet color. Poultry Sci., 81: 1584-1588.

S z a łk ow s k a H., M e 11 e r Z. (1998). The occurrence of PSE and DFD in the meat of chicken broilers (in Polish). Zesz. Nauk. Prz. Hod., 36: 343-348.

S z ku c i k K., P is arski R.K., Nastaj B., Pijarska I., Ma le c H. (2007). Influence of age at slaughter of chicks on butchering characteristics and on the quality of meat tissues (in Polish). Med. Weter., 63 (11): 1353-1356.

V a n L a a ck R.L., L i u C.H., S m ith M.O., L o ve da y H.D. (2000). Characteristic of pale, soft, exudative broiler breast meat. Poultry Sci., 79: 1057-1061.

Krajowa Rada Drobiarstwa - Izba Gospodarcza (2010). Results of the evaluation of Poultry in 2009 (in Polish). Warszawa, pp. 34-65.

Young L.L., Northcutt J.K., Buhr R.J., Lyon C.E., Waret G.O. (2001). Effects of age, sex, and duration of postmortem aging on percentage yield of parts from broiler chicken carcasses. Poultry Sci., 80: 376-379. 


\section{KATARZYNA POŁTOWICZ, JOANNA DOKTOR}

\section{Wpływ wieku uboju wolno rosnących kurcząt brojlerów na produkcyjność i jakość mięsa}

\section{STRESZCZENIE}

Celem badań było określenie wpływu wieku wolno rosnących brojlerów na wyniki odchowu i jakość mięsa. Badaniami objęto mieszańce uzyskane w wyniku krzyżowania kogutów mięsnych Hubbard z kurami polskiej rodzimej rasy Żółtonóżka Kuropatwiana. Kurczęta utrzymywano do 56., 70. lub 84. dnia życia w kurniku na głębokiej ściółce w jednakowych warunkach środowiskowych i żywiono do woli pełnoporcjowymi mieszankami starter, grower i finiszer zawierającymi odpowiednio 20,18 , $15 \mathrm{BO}$ oraz 2825, 2825, $2740 \mathrm{EM} / \mathrm{kg}$ paszy. Po zakończeniu doświadczenia z każdej grupy wiekowej wybrano do uboju po 5 kogutków i 5 kurek, u których przeprowadzono uproszczoną analizę rzeźną. Mięśnie piersiowe i mięśnie nóg poddano ocenie wybranych parametrów technologicznych: pH, barwy, wodochłonności, wycieku swobodnego, strat termicznych i siły cięcia. Wyniki opracowano statystycznie przy pomocy analizy wariancji i testu Duncana. Stwierdzono wpływ długości odchowu na jakość tuszki i mięsa kurcząt. Największe, statystycznie istotne różnice pod względem ocenianych cech wystąpiły między kurczętami ubijanymi w 56. i 84. dniu życia. Najlepszą wydajność rzeźną uzyskały ptaki utrzymywane do 84. dnia życia. Ptaki najmłodsze charakteryzowały się najsłabszym umięśnieniem tuszki i najmniej korzystnymi technologicznymi właściwościami mięsa. Najlepszą efektywność odchowu uzyskano utrzymując mieszańce do 70. dnia życia. 